\title{
POLITIK AKOMODASIONIS ORDE BARU TERHADAP (UMAT) ISLAM: \\ Telaah Historis Kelahiran Perbankan Syariah
}

\author{
Oleh: Noor Azmah Hidayati*
}

\section{Abstract}

This paper tries to study the history of Islamic banking in Indonesia, which has been developing fastly today. With assumption that there is an unseparated relation between economic development and.political factor, the writer argues that the presence of Islamic banking in Indonesia couldn'l be separated with the change of New Order policy which firstly was antiphaty toward Indonesian moslem then became more accommodated to them. The change of this policy ass for the writer caused besides by the need of supporting from Indonesian moslem to the New Order Regime for the balance of the less of military support, also for the awakening of santri's elit that add the bargaining position of their power vis-à-vis the government.

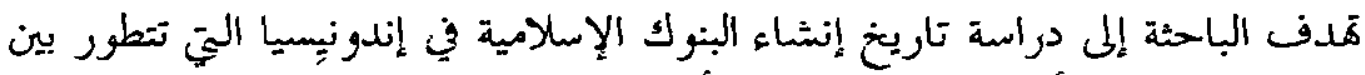

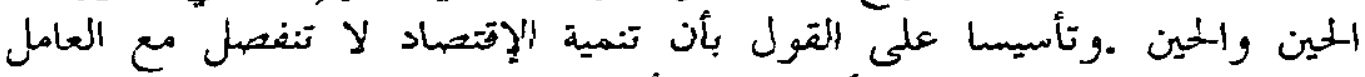

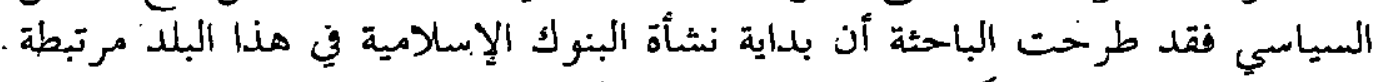

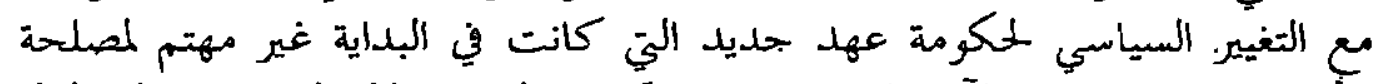

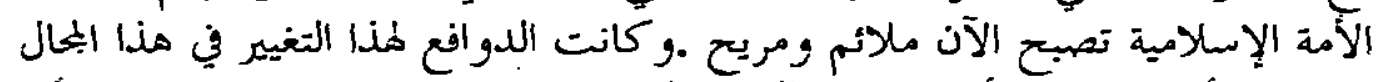

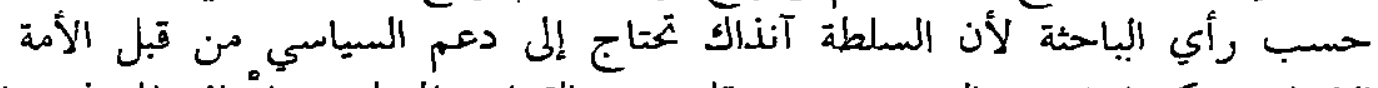

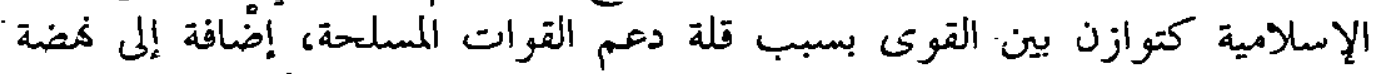

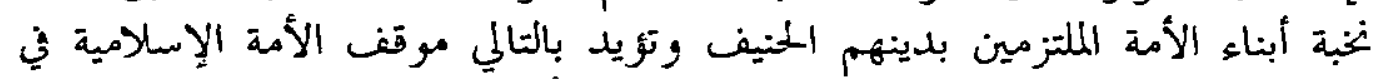

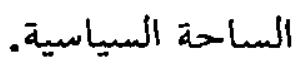

Kata kunci: orde baru, politik Islam, perbankan syariah 


\section{A. Pendahuluan}

Dewasa ini aspek ekonomi dan politik merupakan dua aspek penting yang satu sama lain saling berkaitan, sehingga seakan-akan tidak bisa dilepaskan. Di satu sisi pembangunan ekonomi dipengaruhi oleh faktor politik, di sisi lain politik juga dipengaruhi oleh ekonomi. Realitas inter-dependensi dua hal tersebut telah melahirkan suatu kajian yang dikenal dengan politik ekonomi.

Secara konkret realitas inter-dependensi ekonomi dan politik tersebut, bisa dibaca pada gagasan umat Islam Indonesia untuk mendirikan bank Islam, yang sangat sarat dengan muatan politis. Pada mulanya, hubungan umat Islam dan Orde Baru masih diliputi kecurigaan dan prasangka. Para penguasa Orde Baru pada tahun 1970-an masih mencurigai gagasan tersebut sebagai.salah satu wujud dari gerakan pendirian negara Islam atau realisasi Piagam Jakarta. Oleh karenanya pemerintah tidak mengizinkan pendirian lembaga tersebut. ${ }^{1}$

Namun, pada perkembangan selanjutnya hingga saat ini, ternyata bank syariah mengalami kemajuan yang sangat berarti, bahkan banyak bank konvensional yang membuka divisi syariah. Melihat berbagai perubahan yang cukup pesat dari perkembangan sistem ekonomi Islam yang dimanifestasikan dalam wujud perbankan syariah dan adanya akomodasi dari regulasi perbankan, memunculkan pertanyaan besar, mengapa semua itu bisa terjadi dengan cepat? Dengan adanya asumsi bahwa antara ekonomi dan politik terjadi hubungan inter-depedensi yang sangat erat, maka pertanyaan: peristiwa politik apakah yang memungkinkan itu semua bisa terjadi?

\section{B. Potret Politik Ekonomi Orde Baru}

Dengan kondisi perekonomian Indonesia yang sudah terpuruk, rezim Orde Baru tampil dengan mengusung perlunya stabilisasi, rehabilitasi yang berorientasi pada pembangunan ekonomi. Hal ini tidaklah berlebihan mengingat rakyat Indonesia sudah berkali-kali kecewa akibat krisis-krisis ekonomi pada era Orde Lama. ${ }^{2}$

${ }^{1}$ Alasan resmi yang dikemukakan oleh Pemerintah mengenai tidak diizinkannya pendirian bank Islam adalah karena cara operasi bank Islam, yang menuntut pemerataan lebih adil dengan sistem bagi hasil, dianggap tidak sejalan dengan Undang-undang yang berlaku, yaitu Undangundang No. 14 Tahun 1967, BAB I Pasal 1, yang tidak mengizinkan beroperasinya bank tanpa bunga kredit. Lihat M. Dawam Rahardjo, 2002, "Bank Islam", dalam Ensiklopedi Islam Tematis,Jilid 6, Jakarta: PT Ichtiar Baru Van Houve, hal. 399.

${ }^{7}$ Kelahiran Orde Baru dilatarbelakangi oleh kondisi politik dan ekonomi yang sudah terpuruk. Gagalnya percobaan kudeta G 30 S 1965 berikut perlawanannya telah membawa korban hampir setengah juta jiwa. Kondisi perekonomian saat itu hampir-hampir macet. Sebagaimana yang ditulis oleh Harold Crouch, pada 1965 inflasi di Indonesia mencapai 500\% dan harga beras naik $900 \%$. Defisit anggaran belanja pada tahun itu mencapai $300 \%$ dari pemasukan dan defisit triwulan 
Jenderal Soeharto yang pada saat itu sudah menjabat sebagai presiden cukup menyadari bahwa tugas dari kaum militer bukanlah untuk membuat kebijakan-kebijakan perekonomian. Dia mempercayakan pembuatan kebijakan ekonomi tersebut kepada orang-orang sipil, khususnya kepada sekelompok ahli ekonomi dari Universitas Indonesia yang dipimpin oleh Profesor Widjodjo Nitisastro. Kemudian beberapa anggota dari kelompok ini dikirim ke Universitas California-Berkeley untuk mengadakan pelatihan berkenaan dengan upaya stabilitas ekonomi dalam negeri, ${ }^{3}$ di samping bantuan dari sebuah perutusan dana moneter internasional yang dikirim ke Jakarta untuk pertama kalinya memperjelas posisi hutang luar negeri Indonesia. ${ }^{4}$

Langkah penting pertama untuk menanggulangi inflasi adalah memperbaiki beberapa aturan dalam urusan keuangan pemerintah. Proyek-proyek khusus Presiden Soekarno yang boros dihentikan dan hampir semua proyek pembangunan ditunda. Berbagai upaya dibuat untuk memperbaiki pengawasan atas pengeluaran pemerintah. Untuk pertama kali selama beberapa tahun, sebuah anggaran belanja disusun pada tahun 1967. Dengan pemotongan-pemotongan secara ketat dalam pengalokasiannya, tidak

pertama tahun 1966 hampir sebesar jumlah defisit keseluruhan tahun 1965. Potret buram ekonomi juga terlihat dalam data tentang perdagangan dan pembayaran internasional. Nilai total ekspor 1956 sebesar $\$ 924,4$ juta dan turun menjadi $\$ 790,7$ juta pada 1958 dan pada tahun 1965 angka itu menjadi $\$ 705,9$ juta. Defisit neraca pembayaran juga meningkat antara 1960-1967. Defisit neraca pembayaran juga meningkat antara 1960-1967. Defisit dalam neraca berjalan adalah \$84 juta tahun 1960 dan meningkat secara tajam menjadi \$523 juta, ketika arus bantuan militer dari Uni Soviet melimpah. Pada tahun 1965, defisit itu berjumlah $\$ 248$ juta dan bersamaan dengan itu cadangan valuta asing merosot dari $\$ 313$ juta tahun 1960 menjadi \$8 juta pada April 1966. Padahal pada akhir 1965 Indonesia hanus membiayai kebutuhan impor, minimum berjumlah lebih dari $\$ 600$ juta. Kemudian masih ada lagi masalah hutang luar negeri. Demokrasi terpimpin menciptakan hutang berjumlah $\$ 2.358$ juta, 42\% kepada Uni Soviet, 10\% kepada Jepang dan 7,5\% kepada Amerika Serikat. Pembeayaan hutang ini dijadwalkan selama 7 tahun dimulai pada tahun 1966. Masalah keuangan tersebut menimbulkan dampak yang berat hampir di semua sektor. Tidak adanya mesin suku cadang dan bahan mentah impor, telah menyebabkan produksi industri merosot menjadi kurang $20 \%$ dari kapasitasnya. Kurangnya biaya pemeliharaan juga menyebabkan rusaknya infrastruktur, terutama transportasi dan komunikasi. Hal ini diperparah lagi dengan kondisi hubungan Indonesia dengan luar negeri, terutama setelah dikeluarkannya Indonesia dari keanggotaan PBB dan IMF pada tahun 1965. Pada saat Indonesia harus bersiap-siap membayar kembali hutang luar negerinya yang menumpuk serta memperoleh kredit-kredit baru, negara ini sulit memperoleh status layak kredit. Lihat Mochtar Mas'oed, 1989, Ekonomi dan Struktur Politik Orde Baru 1966-1967, Jakarta: LP3ES, hal. 51.

${ }^{3}$ R. William Liddle, "Regime: The New Order", dalam Donald K. Emmerson (ed), 2001, Indonesia Beyond Suharto Polity Economy Society Transition, New York: M.E. Sharpe, hal. 50.

${ }^{4}$ H.W. Arndt, 1994, Pembangunan Ekonomi Indonesia: Pandangan Seorang Tetangga, Yogyakarta: Gadjah Mada Press, hal. 87. 
terkecuali untuk angkatan bersenjata, anggaran belanja dibuat seimbang pada tahun tiap kuartalnya dan beberapa orang pejabat tinggi Angkatan Darat dilibatkan pada seksiseksi yang bertanggungjawab pada kementerian keuangan untuk mengawasi anggaran ini. Tindakan-tindakan fiskal diperketat oleh pembatasan-pembatasan yang ketat atas kredit perbankan dan dengan menaikkan tingkat suku bunga bank yang lebih mendekati tingkat $15-20 \%$ perbulan..$^{5}$

Melalui tindakan debirokrasi pemerintah berjanji meninggalkan ekonomi komando versi Orde Lama dan membiarkan kekuatan-kekuatan pasar sebanyak mungkin menentukan keputusan-keputusan ekonomi. Karena itu, peraturan pemerintah dan perizinan akan dihapuskan dan badan-badan pemerintah hendak dibuat jadi lebih rasional dan efisien. Kehadiran perusahaan-perusahaan negara akan ditinjau kembali. ${ }^{6}$

Keputusan-keputusan tersebut dipandang oleh pimpinan baru sangat penting guna menstabilkan dan membangun perekonomian serta menarik para kreditor dan investor asing. Sebagai penegasan tentang pendekatan baru atas kebijakan luar negeri (yang telah ditunjukkan dengan mengakhiri konfrontasi dan bergabung kembali kepada PBB) dan sebagai langkah pertama menuju pembaharuan pembangunan ekonomi, sebuah undang-undang penanaman modal asing diundangkan pada tahun 1967. Undang-undang ini memberikan dorongan dan jaminan finansial untuk penanaman modal langsung dari modal asing di Indonesia, baik yang berdiri sendiri maupun berupa perusahaan patungan dengan perusahan-perusahaan Indonesia. ${ }^{7}$

Setelah berhasil menjalin kembali hubungan dengan luar negeri, pemerintah baru ini berusaha mencapai persetujuan untuk penjadwalan kembali dengan para kreditor Iuar negeri Indonesia sehingga beban utang ditangguhkan, dan setiap tahun dirundingkan lagi sampai tahun 1969. Negara-negara Barat dan Komunis dibujuk untuk menerima sebuah penyelesaian jangka panjang dari utang-utang Soekarno. Hal ini menyangkut pembayaran kembali untuk jangka 30 tahun yang dimulai tahun 1970 dengan satu periode yang sifatnya fakultatif bagi sebagian pembayaran modal dan bunga yang tertunda 15 tahun yang terakhir yaitu antara tahun 1985-1999. ${ }^{8}$

Program stabilisasi berhasil di luar dugaan. Sebagai sasaran pertama untuk memperlambat dan menghentikan laju inflasi, di samping perusahaan-perusahaan dalam maupun luar negeri sudah mulai menginvestasikan modalnya secara perlahan. Menurut William Liddle, tanpa langkah-langkah tersebut dapat dipastikan rezim Orde Baru tidak akan mampu bertahan. ${ }^{9}$

${ }^{5}$ Ibid., hal. 88

6 Mochtar Mas'oed, op.cit., hal. 94

${ }^{7}$ H.W. Arndt, op.cit, hal. 89

${ }^{8}$ Ibid.

${ }^{9}$ R. William Liddle, op.cit., hal. 50. 
Dengan bidang usaha yang semakin luas dan berbagai kebijakan yang ada, segelintir orang kemudian menjadi lebih kaya. Tetapi ketidakmerataan yang telah menimbulkan kebencian yang besar tertuju pada oknum-oknum yang kaya melalui korupsi. Di antara mereka adalah pemeran kunci yang terdiri atas sejumlah jenderal yang memegang jabatan sebagai pimpinan dinas-dinas pemerintahan, seperti perusahaan minyak negara dan berbagai badan usaha milik negara lainnya.

\section{Orde Baru dan Politik (Umat) Islam}

Dalam menghadapi berbagai kecaman dan kritikan atas beragam kebijakan yang dijalankannya serta akibat daripadanya, Soeharto kemudian membangun aliansi dengan partai politik, dengan harapan dapat mengerahkan dukungan rakyat terhadapnya. Ada dua partai politik yang dapat memberikan dukungan , yaitu parta NU dan PNI. NU dominan di kalangan santri di kawasan pedesaan maupun di kalangan wiraswasta muslim yang merupakan mayoritas masyarakat bisnis pribumi Indonesia, serta memiliki kepemimpinan yang relatif bersatu. Di pihak lain PNI terkenal di kalangan abangan dan di kalangan pamong praja, birokrasi negara yang terpenting. ${ }^{10}$

Walaupun diketahui bahwa Soeharto adalah seorang muslim, namun dia tidak setuju dengan politik berdasarkan pada agama seperti yang diperjuangkan oleh politisi santri NU. ${ }^{11}$ Akan tetapi karena berbagai pertimbangan, salah satunya adalah karena mayoritas penduduk Indonesia adalah muslim, kiranya memang tidak mudah baginya untuk menolak begitu saja terhadap NU.

Akhirnya diciptakanlah ketertiban politik dengan harapan tidak akan mengganggu program ekonomi pemerintah. Kebijakan tersebut adalah: Pertama, menjadikan "dwi fungsi" ABRI sebagai alat untuk mendistribusikan ganjaran kepada para perwira yang setia kepada pemimpin yang tertinggi dengan menugaskan mereka ke dalam posisi-posisi ekonomi dan politik yang berpengaruh. Kedua, penugasan para perwira militer di posisiposisi birokrasi dan politik untuk menjamin terpeliharanya politik yang tertib dan terkendali dengan mengendalikan konflik faksi-faksi di antara para perwira $\mathrm{AD}$ sendiri dan persaingan antar angkatan dalam tubuh $\mathrm{ABRI}$ serta penyederhanaan politik kepartaian. ${ }^{12}$

${ }^{10}$ Santri dan Abangan adalah dua istilah sosiologis yang sudah akrab di kalangan umat Islam Jawa. Secara kultural, santri digunakan untuk menyebut kelompok muslim yang taat dalam menjalankan agama. Sedangkan abangan sebaliknya, yakni sebutan untuk muslim yang tidak taat dalam menjalankan agama, terutama dalam wilayah ubudiyah. Masing-masing kelompok itu merupakan paguyuban yang seolah-olah saling membuat batas wilayah pergaulan sosiologisnya secara eksklusif. Masing-masing mempunyai budaya dan pola hubungan sosial sendiri-sendiri, sehingga nampak eksklusif. Paparan terkenal untuk pembagian dikotomi ini, lihat Clifford Geertz, 1960, The Religion of Java, London: The Free Press of Glencoe, hal. 6.

"Mochtar Mas'oed, op.cit., hal. 130.

${ }^{12}$ Ibid., hal. 201. 
Diangkatnya Ali Murtopo, yang merupakan salah satu dari dua belas perwira staf pribadi Soeharto, sebagai pembantu politik kepercayaannya memang menunjukkan bahwa Soeharto tidak menyukai radikalisme Islam. Ali Murtopo yang Islam phobia ini bersekutu dengan kelompok Katolik dan tokoh Jawa. ${ }^{13}$ Tidak mengherankan jika kebijaksanaan politik pada awal pemerintahan Orde Baru banyak merugikan kaum muslimin, karena kelompok Ali Murtopo yang memegang kendali pemerintahan didominasi orang-orang yang cenderung memusuhi Islam. Dalam pikiran kelompok ini, Islam merupakan potensi yang amat membahayakan apabila diberi kesempatan. Bagi mereka Islam itu identik dengan "Darul Islam" sehingga mereka cenderung untuk menghancurkannya. ${ }^{14}$

Puncak kegagalan politik Islam untuk kembali berkiprah dalam pemerintahan adalah ketika pemilu pertama Orde Baru pada 1971 yang membawa kemenangan mutlak Golkar yang mengantongi 62,80\% suara atau 392 kursi. ABRI sebanyak 230 kursi, Utusan Daerah dan Golongan 130 kursi, Partai Islam (NU, Parmusi, PSII dan Perti) sebanyak 126 kursi dan partai lain (PNI, Parkindo, Parkat, IPKI dan Murba) memperoleh 42 kursi. ${ }^{15}$ Dengan hanya memperoleh jumlah wakil yang kecil, ruang gerak politik Islam sangat terbatas. Sebaliknya kedudukan pemerintah relatif aman untuk menggolkan agenda politiknya di parlemen. Kemenangan mutlak Golkar juga memberikan legitimasi bagi pemerintah dan militer untuk melakukan kontrol terhadap kehidupan politik.

Kontrol ini kemudian direalisasikan dalam program pengembangan sistem politik hegemonis. Pada Januari 1973, pemerintah memutuskan untuk melakukan restrukturalisasi sistem kepartaian. Dalam struktur politik yang baru ini, seluruh partai, kecuali Golkar, harus bergabung dalam dua partai politik. Keempat partai Islam-NU, Parmusi, PSII dan Perti-digabung dalam PPP (Partai Persatuan Pembangunan). ${ }^{16}$ Sedangkan lima partai lain yang berlatarbelakang nasionalis (PNI, IPKI dan Murba), Kristen Protestan (Parkindo) dan Katolik (Parkat) digabung dalam Partai Demokrasi Indonesia (PDI). ${ }^{17}$

Selain melakukan pengerucutan jumlah partai-partai, pemerintah juga (dalam hal ini golongan mayoritas anggota parlemen adalah Golkar, wakil ABRI, Utusan Daerah dan Golongan) mengusulkan untuk menyejajarkan aliran kebatinan dengan lima agama

${ }^{13}$ Aminuddin, 1999, Kekuatan Islam dan Pergulatan Kekuasaan di Indonesia Sebelum dan Sesudah Runtuhnya Rezim Soeharto, Yogyakarta: Pustaka Pelajar, hal. 75

${ }^{14}$ Afan Gaffar, "Partai Politik, Elit dan Massa dalam Pembangunan Nasional" dalam Ahmad Zaini Abas, 1990, Beberapa Aspek dari Pembangunan Orde Baru, Solo: Ramadhani, hal. 22.

${ }^{15} J a m h a r i, ~ 2002$, "Islam di Indonesia" dalam Ensiklopedi Tematis Dunia Islam, Jilid 6, Jakarta: PT Ichtiar Baru van Hoeve, hal. 359.

${ }^{16}$ Sebuah nama partai yang sama sekali tidak menunjukkan adanya unsur-unsur Islami. Lihat Francois Raillon, 1993, "The New Order and Islam: or the Imbrioglio of Faith and Politics" dalam Indonesia, Cornell Southeast Asia Program, hal. 202.

${ }^{17}$ Jamhari, loc.cit. 
yang telah ada Indonesia, dan dengan mudah mendapat persetujuan. Peminggiran keterlibatan umat Islam kembali dilakukan dengan diberlakukannya asas tunggal. ${ }^{18}$ Sosialisasi Pancasila dengan program P4 (Pedoman Penghayatan dan Pengamalan Pancasila) dilakukan untuk menghindari terjadinya pertentangan ideologi. Lebih dari itu, menurut pemerintah sikap fanatisme terhadap ideologi akan mudah memancing terjadinya kerawanan dan konflik sosial, seperti yang pernah terjadi di Lapangan Banteng Jakarta ketika terjadi bentrokan antar massa PPP dengan Golkar pada 1982.

Walaupun reaksi keras terhadap kebijakan pemerintah ini masih tampak, seperti dalam peristiwa Tanjung Priok pada 12 September 1984, namun umat Islam menyadari bahwa perlawanan konfrontatif tidak akan berhasil. Untuk ini, kalangan cendekiawan muda melakukan reorientasi terhadap makna politik Islam yang selama ini dielaborasi dalam corak legalitas dan formalitas. Orientasi politik baru tersebut lebih mengarah kepada politik substantif dan integratif. Artinya pendekatan baru tersebut lebih mengutamakan kepada aspek kandungan nilai Islam sebagai sumber inspiratif bagi kekuatan politis serta sikap saling menerima dan menyesuaikan antara umat Islam dan negara. ${ }^{19}$

Pada periode 1982-1985, hubungan yang baik Islam dan negara mulai terwujud, walaupun belum sampai pada taraf yang ideal. Adanya Munas ketiga Golkar pada Oktober 1983, menandai awal era baru peranan politik elit Islam di dalam tubuh partai negara Orde Baru. Akbar Tanjung yang berlatarbelakang Ketua Umum HMI bersaing dengan Sarwono Kusumaatmadja, aktivis mahasiswa "Kelompok Bandung" yang mempunyai hubungan patronase dengan Jendral L.B. Moerdani. Keduanya bertarung untuk memperebutkan posisi sebagai Sekjen Golkar. Akbar yang memiliki latarbelakang HMI tentu saja memiliki visi lebih Islam ketimbang Sarwono yang lebih berorientasi sosialis. Kendati dalam pertarungan tersebut Akbar kalah, namun hal tersebut tetap memberikan makna baru bagi perkembangan Golkar ke depan. Golkar yang pada dua dekade pertama Orde Baru lebih dikuasai abangan yang anti Islam, semenjak tampilnya Akbar sebagai kandidat Sekjen, telah memberikan harapan lebih baik bagi tokoh-tokoh gerakan Islam untuk bisa memainkan peranan lebih baik dalam tubuh Golkar di masa berikutnya. ${ }^{20}$

Sementara itu dalam komposisi kepengurusan hasil Munas II Golkar itu, pengaruh dan peranan Ali Murtopo merosot. Jika dalam hasil Munas Golkar 1978 orang-orang dari kelompok ini banyak memegang posisi kunci seperti Sekretaris Jendral, Wakil Ketua

${ }^{18}$ Setelah penerapan asas tunggal ini, semua kekuatatan politik (partai) dan semua organisasi sosial harus menjadikan Pancasila sebagai satu-satunya landasan ideologi partai atau organisasi. Lihat Francois Raillon, op.cit, hal. 204.

${ }^{19}$ Jamhari, op.cit., hal. 360.

${ }^{20}$ Leo Suryadinata, 1992, Golkar dan Militer, Jakarta: LP3ES, haI. 21. 
dan sebagainya, maka produk kepengurusan Golkar 1983, kelompok Ali Murtopo hanya terwakili dua orang dan itu pun tidak menduduki kedudukan yang strategis.

Kemerosotan politik kubu Ali Murtopo ini sangat terkait dengan kesenjangan politik Ali sendiri dengan Soeharto. Ada dua hal yang menyebabkan gap Ali dengan Soeharto yang menyebabkan terpinggirkannya kubu Ali dalam percaturan politik nasional dan di DPD Golkar, khususnya dalam kurun waktu tersebut. Pertama, pada dekade 1970-an Ali Murtopo telah dapat mengerahkan sumber-sumber kekuasaannya sendiri yang dapat menggerogoti kedudukan Soeharto. Kedua, kenyataan yang mendasari krisis politik pada bulan Januari 1974 (Peristiwa Malari) adalah persaingan Ali Murtopo dengan Jendral Soemitro. Berangkat dari kenyataan tersebut, Soeharto di penghujung dekade 1970-an hingga 1980-an secara perlahan-lahan mulai menyusutkan peranan politik Ali Murtopo dan mulai menolch kepada Soedarmono yang berhasil mengelola sekretariat negara, selanjutnya secara resmi diangkat sebagai Wakil Presiden. ${ }^{21}$

Dalam pandangan Soeharto, Soedarmono merupakan sosok yang terlihat tidak mempunyai ambisi politik yang mengkhawatirkan, juga secara intensif berusaha untuk mendekatkan diri kepada ormas-ormas Islam untuk memperoleh simpati dan dukungan. Tentu saja pengangkatan Soedarmono ini menimbulkan rasa keberatan di kalangan militer (AD), terutama "faksi Benny Moerdani" dan Benny merupakan binaan Ali Murtopo. Karena kepemimpinan Soedarmono yang juga diketahui banyak merekrut tokoh-tokoh partai politik santri dan memberikan tempat lebih besar dari kalangan sipil dan ini merupakan ancaman besar bagi eksistensi kelompok Benny. ${ }^{22}$

\section{Kebangkitan Elit Santri: Akomodasi Negara Terhadap Umat Islam}

Dengan berpindahnya arah pandangan Soeharto kepada Soedarmono, telah membuat melemahnya dukungan sebagian perwira tinggi militer terhadap kekuasaan Orde baru. Hal ini memaksa pemerintah untuk meraih dukungan dan legitimasi yang luas dari umat Islam untuk mempertahankan eksistensi kekuasaannya. Dalam konteks inilah banyak "konsesi" diberikan kepada Islam. Kalangan pengamat politik menyebutkan kecenderungan ini sebagai "politik akomodasi" terhadap Islam. ${ }^{23}$

Menurut Bachtiar Effendy, ada dua alasan utama mengapa Orde Baru merekrut kaum muslimin, dalam hal ini para aktivis dan cendekiawan muslim. Pertama, dari sudut sosiologis, sejak terbukanya akses pada pendidikan dan aktivitas ekonomi, yang memberikan para cendekiawan banyak kesempatan untuk menempuh pendidikan di luar negeri. Pulangnya mereka dari menuntut ilmu disertai dengan mobilitas sosial

${ }^{21}$ Mochtar Mas'oed, op.cit., hal. 179.

${ }^{22}$ Aminuddin, op.cit., hal. 182.

${ }^{23}$ Hairus Salim, 2004, "Sejarah Kebijaksanaan Kerukunan" dalam BASIS, Tahun ke-53, No. 01-02, Januari-Fcbruari, hal. 35. 
menjadikan nilai tawar umat Islam semakin tinggi sehingga mereka harus diakomodasi ke dalam struktur negara. Kedua, peningkatan kualitas pendidikan umat Islam serta kemampuan cendekiawan Islam dalam melontarkan gagasan pemikiran Islam sehingga membuat pemerintah tidak mungkin mengabaikan keberadaan mereka, apalagi karena pemikiran-pemikiran tersebut dalam beberapa hal sesuai dengan arah dan kebijakan politik yang dikembangkan Orde Baru. ${ }^{24}$

Selanjutnya, bentuk akomodasi pemerintah Orde Baru terhadap Islam ada empat macam, yaitu akomodasi struktural, akomodasi legislatif, akomodasi infrastruktural dan akomodasi kultural. Yang dimaksud dengan akomodasi struktural adalah diakomodasinya atau direkrutnya para tokoh muslim pada lembaga-lembaga eksekutif (birokrasi) dan lembaga-lembaga legislatif negara. Mengenai akomodasi secara struktural ini baru terlihat dengan jelas ketika Presiden Soeharto menyetujui didirikannya ICMI (Ikatan Cendekiawan Muslim Indonesia) pada 1990. Sedangkan akomodasi legislatif berkaitan dengan dikeluarkannya undang-undang atau peraturan-peraturan yang berkaitan dengan Islam sebagai aturan yang mandiri dan sah. Di antara kebijakan akomodasi ini adalah pengesahan UU Pendidikan Nasional tahun 1989, pemberlakuan undang-undang peradilan agama, diperbolehkannya pemakaian jilbab pada tahun 1991 serta disahkannya undang-undang yang berkaitan dengan perbankan syariah di Indonesia pada tahun 1992.

Adapun akomodasi infrastruktural adalah penyediaan infrastruktur yang diperlukan umat Islam untuk melakukan kewajiban-kewajban agama mereka. Salah satu bentuk dari akomodasi ini adalah kesediaan pemerintah, bukan hanya mengizinkan, tapi juga membantu pendirian Bank Muamalat Indonesia (BMI) pada 1991. Sementara itu akomodasi kultural adalah diperbolehkannya secara luas berbagai ekspresi kebudayaan yang dipahami sebagai budaya Islam. ${ }^{25}$

Pembentukan ICMI pada 7 Desember 1990 di Kampus Universitas Brawijaya, Malang, dianggap sebagai momentum sejarah penting bagi umat Islam. Perkembangan itu tidak saja berarti mulai mencairnya hubungan Islam dan negara melainkan juga telah ditemukannya rumusan mengenai hubungan Islam dengan negara yang integral dan sesuai dengan kultur Indonesia. ${ }^{26}$ ICMI menandai era baru umat Islam setelah periode lama yang dicirikan oleh adanya kendala ideologis dan psikologis antara umat Islam dan negara. Dengan demikian ICMI mempunyai dwi makna politik: Pertama, dari sudut pemerintah, hal ini berarti bertambahnya dukungan politis. Kedua berarti pula terbukanya peluang lebil besar bagi umat Islam untuk turut berpartisipasi dalam perpolitikan negara.

${ }^{24}$ Bachtiar Effendy, 1998, Islam dan Negara: Transformasi Pemikiran dan Praktek Politik Islam di Indonesia, Jakarta: Paramadina, hal. 37-38.

${ }^{25}$ Ibid., hal. 40-45.

${ }^{26}$ Jamhari, op.cit, , hal. 362. 
Sikap pro dan kontra terhadap keberadaan ICMI di kancah perpolitikan Indonesia menunjukkan betapa organisasi ini mempunyai bobot politik yang tinggi. Walaupun secara tegas Ketua ICMI, Prof. Dr. B. J. Habibie, pada tanggal 10 September 1993 menyatakan bahwa ICMI bukanlah sebuah kekuatan politik dan tentu saja bukan merupakan sebuah partai politik baru. ICMI merupakan sebuah organisasi intelektual yang berusaha untuk mengembangkan sumber daya manusia Indonesia. ${ }^{27} \mathrm{Hal}$ ini juga disebabkan karena ICMI menjadi wadah peleburan berbagai kelompok dan aliran di kalangan umat Islam, seperti NU, Muhammadiyah, DDII, dan Persatuan Islam (Persis).

\section{E. Lahirnya Perbankan Syariah di Indonesia}

Di Indonesia, gagasan untuk mendirikan perbankan bagi hasil bermula dari adanya perdebatan mengenai apakah bunga bank itu identik dengan riba, dan hal ini cukup kontroversial. Pendapat pertama beranggapan bahwa bunga bank itu termasuk riba, ${ }^{28}$ oleh karena mengandung unsur tambahan (ziyâdah) serta tanpa risiko (muqabil). Unsur tambahan ini disyaratkan di dalam akad dan dapat mengandung unsur pemerasan. Pendapat kedua, menghalalkan bunga bank, karena adanya unsur sukarela antar kedua belah pihak, tidak ada unsur pemerasan dan mempunyai fungsi untuk kepentingan umum. Selain itu juga tambahan yang disyaratkan tidaklah dalam jumlah yang besar. ${ }^{29}$

Dari kedua pendapat tersebut, pendapat pertamalah yang lebih dominan dipegang umat Islam. Akibatnya banyak dari mereka enggan untuk berhubungan dengan perbankan (konvensional). Padahal dalam era Orde Baru yang menekankan pada pertumbuhan ekonomi, kemampuan kompetisi masyarakat dalam hal akumulasi kapital tidak bisa dilepaskan dari peranan lembaga perbankan. Akibatnya sebagian masyarakat muslim menjadi masyarakat yang tertinggal dari segi ekonomi dibandingkan dengan masyarakat kelompok lain. ${ }^{30}$

Berangkat dari persoalan tersebut, beberapa kalangan tokoh Islam berusaha untuk mendirikan bank yang sesuai dengan syariat Islam. Dengan demikian akan dapat mendorong masyarakat muslim mengintegrasikan dirinya dengan sistem perekonomian modern dan sekaligus mendorong produktivitas ekonomi yang pada gilirannya akan

${ }^{27}$ Darul Aqsha, et.al., 1995, Islam in Indonesia: A Survey of Events and Development From 1988 to March 1993, Jakarta: INIS, hal. 275.

${ }^{28}$ Penjelasan-penjelasan tentang bunga bank sama dengan riba dapat dilihat dalam Afzalur Rahman, 2002, Doktrin Ekonomi, ter. Nastangin dan Soeroyo, Jilid III, Yogyakarta: Dana Bhakti Wakaf, hal. 13-225. Lihat juga Adiwarnan Karim, 2001, Ekonomi Islam Suatu Kajian Kontemporer, Jakarta: Gema Insani Press, hal. 72-74.

${ }^{29}$ Cendekiawan Muslim yang menganut paham ini adalah Sjafruddin Prawiranegara, Kasman Singodimedjo dan Mohammad Hatta. Lihat Dawam Rahardjo, op.cit., hal. 399.

${ }^{30}$ Aminuddin, op.cit., hal. 284. 
memberdayakan perekonomian umat Islam. Ide pendirian bank syariah ini sebenarnya sudah muncul sekitar tahun 1970-an atau pada masa awal Orde Baru. Gagasan ini pada mulanya dicurigai sebagai bagian dari sisa-sisa gagasan Negara Islam, karenanya tidak diizinkan oleh pemerintah. Alasan resmi yang mereka kemukakan adalah dengan membenturkan pada perangkat perundang-undangan perbankan yang pada saat itu memang tidak memberikan ruang bagi beroperasinya bank tanpa bunga. Undang-undang tersebut adalah UU Pokok Perbankan No. 14/1967 Bab I, yang mengharuskan setiap transaksi kredit disertai dengan bunga. ${ }^{31}$

Ide ini kembali digulirkan pada tahun 1973, tetapi gagasan ini belum dapat terwujud karena kurangnya modal yang diperlukan bagi pendirian sebuah bank. Akhimya gagasan ini kembali dikemukakan pada lokakarya yang diselenggarakan di Cisarua, Bogor pada 19-20 Agustus 1990. Ide pertamanya berasal dari Majelis Ulama Indonesia (MUI) yarig kemudian didukung dan diprakarsai oleh beberapa pejabat penting pemerintah, para pengusaha yang berpengalaman di bidang perbankan. ${ }^{32}$ Sekalipun status hukum bunga bank masih mengambang dalam lokakarya tersebut, forum telah berhasil menyepakati untuk mendirikan bank bebas bunga yang sejalan dengan syariat Islam. Rekomendasi dari lokakarya tersebut ditindaklanjuti dengan Musyawarah Nasional MUI ke IV dengan menugaskan Dewan Pimpinan MUI untuk memprakarsai pendirian bank tersebut . Suatu tim perbankan MUI yang diketuai oleh Dr. Ir. M. Amin Aziz dibantu oleh tim hukum ICMI yang diketuai oleh Drs. Karnaen Purwaatmaja, MPA..$^{33}$

Dalam mewujudkan "proyek" tersebut, MUI kemudian membentuk Yayasan Dana Dakwah Pembangunan dengan Ketua Umumnya K.H. Hasan Basri dan Sekretaris Umum DR. H. Amin Aziz, yang kemudian menyiapkan tiga puluh tenaga perbankan untuk mengikuti training di Lembaga Pelatihan Perbankan Indonesia (LPPI) di Jakarta selama tiga bulan pada bulan Maret 1991 dengan harapan para peserta tersebut nantinya bisa memberikan pelatihan lebih lanjut pada kader-kader muda perbankan, baik konvensional maupun syariah..$^{34}$

Tim ini juga bekerja secara giat melakukan pendekatan-pendekatan kepada pihak-pihak yang bersimpati dengan pendirian bank tanpa bunga ini terutama para pejabat yang terkait dengan urusan moneter. Tim perbankan ini juga menyadari bahwa tindakan gegabah akan dapat berakibat gagalnya usaha pendirian bank syariah ini. Kewaspadaan ini berdasarkan hasil SWOT yang berhasil mengidentifikasikan dua ancaman yang

${ }^{3 t}$ M. Dawam Rahardjo, op. cit., hal. 399-400.

${ }^{32}$ Zainul Arifin, 2000, Memahami Bank Syariah: Lingkup, Peluang, Tantangan dan Prospek, Jakarta: Alvabet, hal. 17.

${ }^{33}$ Aminuddin, op. cit., hal. 285.

${ }^{34}$ Darul Aqsha, et.al., op. cit., hal. 184. 
mungkin dihadapi dalam mewujudkan berdirinya bank syariah tersebut. Pertama, pengoperasian Bank Muamalat Indonesia (BMI) dikait-kaitkan dengan fanatisme agama. Akan ada pihak-pihak yang menghalangi berdirinya BMI semata-mata karena tidak suka akan kebangkitan umat Islam dari keterbelakangan ekonominya. Isu eksklusivisme ataupun SARA mungkin dilontarkan untuk mencegah berkembangnya bank syariah di Indonesia.

Kedua, ancaman dari mereka yang terganggu oleh sistem operasional yang bebas bunga. Munculnya bank syariah yang menuntut adanya sistem bagi hasil yang lebih adil akan dirasakan sebagai ancaman terhadap status-quo yang telah mereka nikmati. Mereka mungkin akan menghambat pendirian bank syariah ini dengan menghadapkannya pada perangkat perundang-undangan yang pada saat itu memberlakukan bunga atas setiap transaksi kredit perbankan, yaitu UU Pokok Perbankan No. 14/1967 Bab I. ${ }^{35}$

Di luar dugaan ternyata proses pendirian Bank Muamalat Indonesia (BMI) tidak terlalu banyak mengalami hambatan. Walaupun pada awalnya Menteri Agama Munawir Sjadzali mengungkapkan rasa pesimisnya ketika para tim perbankan ini mulai mengadakan audiensi. Walaupun demikian, Munawir tetap memberikan izin, sehingga pendekatanpendekatan kepada para pejabat pun terus dilakukan. Para pejabat yang dihubungi tersebut adalah Dirjen Moneter Oskar Surjaatmadja, Menteri Muda Keuangan Nasruddin Sumintapura dan Menteri Perdagangan, Arifin Siregar. ${ }^{36}$

Selanjutnya, pada tanggal 21 Februari 1991, tim perbankan MUI bersilaturrahmi dengan Menteri Kehakiman, Ismail Saleh dan memperoleh tanggapan positif dengan menyatakan kesediaannya untuk memperlancar berdirinya badan hukum bank tanpa bunga tersebut. Bahkan pada tanggal 29 Maret 1991, Menteri Muda Keuangan, Nasruddin Sumintapura bersedia membuka acara di LPPI. Dalam sambutan training tersebut, Sumintapura mengungkapkan bahwa bank syariah harus mampu untuk menstimulasi aktivitas investasi masyarakat Indonesia yang mayoritas beragama Islam. Dengan meningkatnya investasi, diharapkan dapat menolong masyarakat ekonomi lemah, khususnya masyarakat yang kekurangan modal dalam berusaha. ${ }^{37}$

Dari beberapa menteri tersebut, Menristek dan Ketua Umum ICMI, B.J. Habibie yang terlihat paling antusias menyatakan dukungannya terhadap pendirian bank syariah. Segera Habibie menggalang dana pensiun dari tiga industri yang berada di bawah kendalinya dan berhasil mengumpulkan dana sebesar Rp. 63 miliar. Jumlah uang tersebut terus bertambah manakala tim perbankan MUI ini dipanggil oleh Menteri Perindustrian

\footnotetext{
${ }^{35}$ Aminuddin, op. cit., hal. 286.

${ }^{36}$ Ibid.

${ }^{37}$ Darul Aqsha, op. cit., hal. 185.
} 
untuk diberikan dana tambahan dari beberapa perusahaan yang pemiliknya kebanyakan bukan orang Islam, termasuk di dalamnya Salim Group..$^{38}$

Menteri Sekretaris Negara yang bertugas untuk menghubungi Presiden Soeharto, kemudian beliau berkenan untuk menerima tim perbankan MUI ini pada 27 Agustus 1991. Dalam pertemuan tersebut ternyata Presiden menyambut rencana tersebut dengan antusias dan bersedia dicantumkan sebagai pemrakarsa bank syariah sekaligus memberikan dana Rp. 3 miliar dari kas Yayasan Amal Bhakti Muslim Pancasila tanpa bunga dan tanpa batas waktu pengembalian. Selanjutnya Presiden juga berjanji untuk membantu kekurangan modal awal yang diperlukan untuk pendirian bank syariah ini dengan menggelar sarasehan di Istana Bogor pada 3 Nopember 1991 yang berhasil dihadiri sekitar 4.600 undangan. Para undangan yang hadir saat itu sangat beragam, mulai dari para pedagang kaki lima sampai para menteri dan konglomerat, tak terkecuali pejabat moneter Menkeu, JB. Sumarlin dan Gubernur Bank Indonesia, Adrianus Mooy. Saham yang dijual seharga Rp. 1000 per lembar itu pun dalam waktu dua jam berhasil menyedot dana masyarakat sekitar Rp. 25 miliar. Secara pribadi, Presiden juga membeli saham BMI seharga Rp. 50 juta ${ }^{39}$

Selain keterlibatan Presiden beserta menteri-menterinya tersebut, kehadiran perbankan syariah juga didukung oleh adanya kebijakan deregulasi perbankan tahun 1983 yang telah memberikan keleluasaan penentuan tingkat suku bunga, termasuk nol persen. Selanjutnya hadirnya Paket Oktober 1988 (Pakto 88) semakin memperkuat kehadiran perbankan dengan diperbolehkannya menerapkan bunga nol persen. ${ }^{40}$ Menjelang berdirinya BMI, kemudian ditetapkan UU No.7/1992 Tentang Perbankan, dimana bank bagi hasil diakomodasikan. Pada 1 November 1991 ditandatangani Akte Pendirian PT. Bank Muamalat Indonesia (BMI) dengan Akte Notaris Yudo Paripurno, S.H. dan izin Menteri Kehakiman No. 2.2413.HT.01.01 serta izin Menteri Keuangan pada tanggal 5 November 1991. Dengan izin usaha yang dikeluarkan berdasarkan Keputusan Menteri Keuangan tanggal 24 April 1992, maka BMI mulai beroperasi tanggal 1 Mei $1992 .{ }^{41}$

${ }^{38}$ H. Karnaen A. Parwaatmadja, 1992, "Peluang dan Strategi Operasional BMI", dalam Berbagai Aspek Ekonomi Islam, Yogyakarta: Tiara Wacana, hal. 148.

${ }^{39}$ Lihat Aminuddin, op. cit., hal. 287-290.

${ }^{40}$ Lihat Muhammad, "Dasar Falsafah dan Hukum Bank Syariah" dalam Muhammad (ed), 2002, Bank Syariah, Analisis Kekuatan, Kelemahan, Peluang dan Ancaman, Yogyakarta: Ekonisia, hal. 58 .

${ }^{41}$ M. Dawam Rahardjo, op. cit., hal. 403. 


\section{F. Penutup}

Berangkat dari paparan sebelumnya, catatan yang bisa dikemukakan bahwa politik-ekonomi Islam di Indonesia menjelang lahirnya perbankan syariah Indonesia cukup memainkan peranan yang signifikan. Sebagai buah dari bangkitnya kaum 'elit santri', maka daya tawar umat Islam vis-à-vis penguasa semakin tinggi. Terlebih penguasa (Soeharto) pada saat itu sangat membutuhkan dukungan dari umat Islam, sebagai balance dari mulai berkurangnya dukungan militer. Bisa dikatakan telah terjadi 'bulan madu' antara umat Islam dengan penguasa, yang memungkinkan akomodasi terhadap kepentingan umat Islam, termasuk di antaranya masalah pendirian perbankan syariah. Eksistensi perbankan syariah sendiri secara kebetulan cukup diuntungkan dengan krisis ekonomi, yang telah membuat kolaps banyak perbankan konvensional, sementara perbankan syariah malah memperlihatkan ketangguhan dan kinerja yang cukup memuaskan.

\section{DAFTAR PUSTAKA}

Ahmad, Mohtar, 1991, "Kajian Ekonomi dan Nilai Islam", dalam Jurnal Clumul Qur 'an Vol. II, No. 9.

Aminuddin, 1999, Kekuatan Islam dan Pergulatan Kekuasaan di Indonesia Sebelum dan Sesudah Runtuhnya Rezim Socharto, Yogyakarta: Pustaka Pelajar.

Arifin, Zainul, 2000, Memahami Bank Syariah: Lingkup, Peluang, Tantangan dan Prospek, Jakarta: Alvabet.

Aqsha, Darul et.al., 1995, Islam in Indonesia: A Survey of Events and Development From 1988 to March 1993, Jakarta: INIS.

Arndt, H.W., 1994, Pembangunan Ekonomi Indonesia: Pandangan Seorang Tetangga, Yogyakarta: Gadjah Mada Press.

Asfar, M., 1996,"Ulama dan Politik Perspektif Masa Depan" dalam Jurnal Ulumul Qur'an, Vol. VI, No. 5.

Effendy, Bachtiar, 1998, Islam dan Negara: Transformasi Pemikiran dan Praktk Poitik Islam di Indonesia, Jakarta: Paramadina. 
Gaffar, Afan "Partai Politik, Elit dan Massa dalam Pembangunan Nasional" dalam Ahmad Zaini Abas, 1990, Beberapa Aspek dari Pembangunan Orde Baru, Solo: Ramadhani

Geertz, Clifford, 1960, The Religion of Java, London: The Free Press of Glencoe.

Hefner, Robert W., 1995, ICMI dan Perjuangan Menuju Kelas Menengah Indonesia, Yogyakarta: Tiara Wacana.

Jamhari, 2002, "Islam di Indonesia" dalam Ensiklopedi Tematis Dunia Islam, Jilid 6, Jakarta: PT Ichtiar Baru van Hoeve.

Karim, Adiwarman, 2001; Ekonomi Islam Suatu Kajian Kontemporer, Jakarta: Gema Insani Press.

Liddle, R. William, "Regime: The New Order", dalam Donald K. Emmerson (ed), 2001, Indonesia Beyond Suharto Polity Economy Society Transition, New York: M.E. Sharpe

Mas'oed, Mochtar, 1989, Ekonomi dan Struktur Politik Orde Baru 1966-1967, Jakarta: LP3ES.

Muhammad (ed.), 2002, Bank Syariah, Analisis Kekuatan, Kelemahan, Peluang dan Ancaman, Yogyakarta: Ekonisia.

Purwaatmadja, H. Karnaen A., 1992, "Peluang dan Strategi Operasional BMI", dalam Berbagai Aspek Ekonomi Islam, Yogyakarta: Tiara Wacana.

Rahardjo, M. Dawam, 2002, "Bank Islam”, dalam Ensiklopedi Islam Tematis, Jakarta: PT Ichtiar Baru Van Houve.

Rahman, Afzalur, 2002, Doktrin Ekonomi, ter. Nastangin dan Soeroyo, Jilid III, Yogyakarta: Dana Bhakti Wakaf.

Raillon, Francois 1993, "The New Order and Islam: or the Imbrioglio of Faith and Politis" dalam Indonesia, Cornell Southeast Asia Program 
62

Salim, Hairus, 2004, "Sejarah Kebijaksanaan Kerukunan," dalam BASIS, Tahun ke53, No. 01-02, Januari- Februari.

Suryadinata, Leo, 1992, Golkar dan Militer, Jakarta: LP3ES.

Wahid, Agus 1995, "ICMI Langkah Strategis Menuju Pemberdayaan Umat Berkualitas?" dalam Jurnal Ulumul Qur'an, Vol. VI, No. 4. 